\title{
New Paradigm of Indonesian Criminal Law Policy to Formulate Sanctions for Cases of Customary Crimes
}

\author{
I Made Wirya Darma* \\ DOI: https://doi.org/10.22304/pjih.v8n2.a6
}

Submitted: March 29, 2021 | Accepted: August 20, 2021

\begin{abstract}
Legal politics examines changes within present law due to consistent demands and needs of people. Legal politics continue to develop the rule of law, from the Ius Constitutum, which is based on the previous legal framework, to the formulation of the law in the future, the lus Constituendum. The Indonesian 2019 draft of Criminal Code formulates customary sanctions as the fulfillment of customary obligations in several articles. These articles provide a new paradigm of criminal law policy to formulate criminal law reform in the future for customary sanctions in cases of customary crimes. The study used normative juridical or library research on normative legal substances. It aims to reveal the truth based on scientific logic from the normative side by examining library materials or secondary data consisting of primary and secondary legal materials. The results show that the fulfillment of customary obligations can be expected to become criteria or signs/guidelines for judges to determine "law that lives in society" or "The Living Law" as a source of law (material legality) in the future. It is a form of new paradigm in the renewal of customary criminal law. Thus, customary (criminal) law can become (1) a positive source of law, in the sense that customary criminal law (sanctions) can be the legal basis to examine cases at the Court; and (2) negative sources of law, in the sense that the provisions of customary criminal law (sanctions) can be justified reasons, reasons for mitigating punishment or providing more severe punishment.
\end{abstract}

Keywords: criminal law, customary sanctions, customary crimes.

\section{Paradigma Baru Kebijakan Hukum Pidana dalam Formulasi Sanksi dalam Kasus Delik Adat}

\begin{abstract}
Abstrak
Politik hukum mengkaji berbagai perubahan pada hukum di tengah masyarakat yang didasari tuntutan dan kebutuhan masyarakat yang senantiasa berkembang. Politik hukum berusaha meneruskan arah perkembangan tertib hukum, dari lus Constitutum yang bertumpu pada kerangka landasan hukum yang terdahulu menuju pada penyusunan hukum di masa datang atau lus Constituendum. Rancangan Undang-Undang Kitab UndangUndang Hukum Pidana Tahun 2019 merumuskan ketentuan sanksi adat sebagai

PADJADJARAN Journal of Law Volume 8 Number 2 Year 2021 [ISSN 2460-1543] [e-ISSN 2442-9325]

Lecturer of the Faculty of Law and Social Science, Universitas Pendidikan Nasional, Jl. Bedugul No. 39, Sidakarya, Kec. Denpasar Sel., Kota Denpasar, Bali 8022, Dr., S.H., M.H. (Universitas Brawijaya), wiryadarma@undiknas.ac.id.
\end{abstract}


pemenuhan kewajiban adat dalam beberapa pasal. Pasal-pasal tersebut memberikan paradigma baru kebijakan hukum pidana dalam perumusan sanksi adat untuk kasus tindak pidana adat sebagai pembaharuan hukum pidana di masa yang akan datang. Kajian ini menerapkan metode yuridis normatif atau penelitian kepustakaan yang berkaitan dengan substansi hukum yang bersifat normatif. Metode ini dipilih untuk menemukan kebenaran berdasarkan logika keilmuan dari sisi normatif, dengan meneliti bahan pustaka atau data sekunder yang terdiri atas bahan hukum primer dan bahan hukum sekunder. Hasil penelitian ini bahwa perumusan Pasal 2 ayat (2) RUU KUHP tahun 2019 mengenai pemenuhan kewajiban adat dapat diharapkan menjadi kriteria atau ramburambu/pedoman bagi Hakim dalam menetapkan "hukum yang hidup dalam masyarakat" atau "the living law" sebagai sumber hukum (legalitas materiil) di masa yang akan datang sebagai bentuk paradigma baru dalam pembaharuan hukum pidana adat. Dengan demikian, hukum (pidana) adat dapat menjadi: (1) Sumber hukum yang positif, dalam arti hukum pidana adat (sanksi adat) dapat menjadi dasar hukum pemeriksaan perkara di Pengadilan Negeri; dan (2) Sumber hukum yang negatif, dalam arti ketentuan-ketentuan hukum pidana adat (sanksi adat) dapat menjadi alasan pembenar, alasan meringankan pidana atau memperberat pidana.

Kata Kunci: hukum pidana, sanksi adat, tindak pidana adat.

\section{A. Introduction}

Changes and reforms in Indonesian criminal law, especially ones that related to material (substantive) criminal law, are important and fundamental. The present law, especially the still-in-use colonial material criminal law, is no longer able to meet the legal needs of the Indonesian people. This is in accordance with the legal reality that the current criminal law or the KUHP (Kitab Undang-Undang Hukum Pidana, the Indonesian Criminal Code) does not originate from the concepts of Indonesian basic values, socio-political, socio-economic, and socio-cultural realities. The renewal of the national criminal law is one of the big problems faced by the Indonesian. It covers mainly the replacement of the KUHP (WvS) that is inherited from the Dutch colonial era. The KUHP is now still in effect. However, it is considered no longer in accordance with the demands and values that develop within the people. Indonesia needs a New Criminal Code, which has national characters in nature and in line with the national perspective, which is rooted in social values, culture, and the structure of Indonesian people. ${ }^{1}$

The reform of criminal law is inseparable from the task of legal politics to examine the prospective changes to the existing law. Therefore, it can meet new demands and needs of the people. Legal politics tries to continue the development of the rule of law, from the lus Constitutum, which is based on the previous legal framework, to the law formulation in the future or the lus Constituendum. ${ }^{2}$ Legal politics hand over legislative authority to state administrators but with due regard

\footnotetext{
Rahmat Hi. Abdulah, "Urgensi Hukum Adat dalam Pembaharuan Hukum Pidana Nasional”, Fiat Justisia Jurnal Ilmu Hukum, Vol. 9, No. 2, 2015, p. 169.

Ibid, p. 170.
} 
to the values prevailing in society, all of which are directed towards achieving the aspired state goals. Indonesia seems to compile legal politics in a systematic and programmed manner both for reason as a former colony and for ideological reasons of the rechtsidea mandate. It is the legal ideals contained in the 1945 Constitution.

Criminal law reflects a nation's political ideology. It is important that the entire legal structure rests on a sound and consistent political view. The view of criminal law is closely related to the general views of law, of state and society, and of crime. ${ }^{3}$ The politics of criminal law is basically a form of policy that responds to the development of human thinking of crime. The criminal codes of Western European states are individualistic in nature. The Eastern European states tends to be socialists. Indonesia has Pancasila as the political view. Pancasila conceptually provides space for the sanctioning of laws within society. In this regard, the renewal of the Indonesian Criminal Code provides opportunity of the inclusion of customary sanctions.

The Decree of the Provisional People's Consultative Assembly Number XX/ MPRS/1996 on the Values of Pancasila regulates that Pancasila is essentially a view of life, awareness, and legal ideals, as well as noble moral ideals that includes the psychological atmosphere and character of the people of Indonesia. Indonesian legal reform is based on Pancasila as the guide and source of state law. Therefore, every rule made must reflect the values of belief in God, Humanity, Unity, Democracy, and Social Justice. These values must also exist in the Indonesian Criminal Law. Based on its position, Pancasila is the highest source of law. It means that Pancasila is a parameter of Indonesian law assessment. Article 2 of the Law Number 12 of 2011 on the Establishment of Legislation states that Pancasila is the source of all sources of state law. The rule of law within the society must reflect awareness and a sense of justice which are in accordance with the personality and philosophy of Indonesian people. In addition, Pancasila is also a reference to limit the Customary Criminal Law. Therefore, any customary criminal law that contradicts Pancasila must be considered invalid. ${ }^{4}$

The main source of Indonesian criminal law is written. However, certain areas and societies in Indonesia also recognize customary criminal law. Some indigenous peoples for generations continuously agree a kind of legal agreement on prohibited or allowed deeds. Violation on a prohibition can be sanctioned to bring justice, both for violator and victim. It is also intended to realize justice for the whole members of indigenous community. According to experts of customary criminal

I Dewa Made Suartha, Hukum dan Sanksi Adat Perspektif Pembaharuan Hukum Pidana, Malang: Setara Press, 2015, p. 277.

4 Asliani Harahap, "Pembaharuan Hukum Pidana Berbasis Hukum Adat", EduTech: Jurnal Ilmu Pendidikan dan IImu Sosial, Vol. 4, No. 2, 2018, p. 5. 
law, the needs of justice realization is a restoration of a balance that has been disturbed. Therefore, customs can become source of national criminal law.

The source of the law is public awareness on fairness of orderly and peaceful social life regulation. Therefore, the source of the law must comply fair rules/norms of life. It must be in accordance with the feelings and awareness of the law (values) of the community to create a peace and order based on the interests of the community. Therefore, the renewal of criminal law must be carried out thoroughly and systematically by considering the values within society. For this reason, the measure to criminalize an act depends on people values and collective views. Von Savigny says, das rechts wird nicht gemacht, es ist und wird mit dem volke (the law is not made, it exists and develops with the soul of the nation). Thus, what is described in the customary criminal law is about events and actions that constitute the offenses and the resolution to restore the balance within the society. ${ }^{5}$

According to Sudarto, ${ }^{6}$ the legal basis for the application of Customary Criminal Law during the Dutch East Indies era lies in Article 131 IS in conjunction with $A B$ (Algemene Bepalingen van Wetgeving). During the promulgation of the 1950 Provisional Constitution, several articles that can be used as a basis are Articles 32, 43 paragraph (4), 104 paragraph (1), 14, 13 paragraph (32) and 16 paragraph (2).

However, there is actually no need for a legal basis taken from the provisions of the law, because Customary Criminal Law or Customary Law is the original law and all the originals apply automatically, unless there are things that prevent them. However, there is another legal foundation in Article 5 paragraph (3) sub b of Emergency Law Number 1 of 1951 (LN, 1951-9) which reads as follows. ${ }^{7}$

"Hukum materiil sipil dan untuk sementara waktu pun hukum materiil pidana sipil yang sampai kini berlaku untuk kaula-kaula daerah Swapraja dan orang-orang yang dahulu diadili oleh Pengadilan Adat, ada tetap berlaku untuk kaula-kaula dan orang itu dengan pengertian bahwa suatu perbuatan yang menurut hukum yang hidup harus dianggap perbuatan pidana, akan tetapi tiada bandingannya dalam Kitab Hukum Pidana Sipil, maka dianggap diancam dengan hukuman yang tidak lebih dari tiga bulan penjara dan atau denda lima ratus rupiah, yaitu sebagai hukuman pengganti bilamana hukuman adat yang dijatuhkan tidak diikuti oleh pihak yang terhukum dan penggantian yang dimaksud dianggap sepadan oleh Hakim dengan dasar kesalahan terhukum."

["The civil material law and for the time being, also the civil criminal material law, which until now applies to the subjects of the Swapraja

Fery Kurniawan, "Hukum Pidana Adat sebagai Sumber Pembaharuan Hukum Pidana Nasional", EDUKA Jurnal Pendidikan, Hukum, dan Bisnis, Vol. 2, No. 2, 2016, pp. 12-13.

Sudarto, Hukum Pidana I, Semarang: Yayasan Sudarto, 2009, p. 28.

Galuh Faradhilah Yuni Astuti, "Relevansi Hukum Pidana Adat dalam Pembaharuan Hukum Pidana di Indonesia", Jurnal Pandecta, Vol. 10, No. 2, 2015, p. 196. 
(self-government) area and people who were previously tried by the Customary Court, still applies to these subjects and that person with the understanding that an act, which is according to living law must be considered a criminal offense, but it is unequal in the Civil Criminal Code, is considered punishable by a sentence of no more than three months imprisonment and/or a fine of five hundred rupiahs, as a substitute penalty if the customary sentence imposed is not followed by the convicted party and the compensation in question is deemed equal by the judge on the basis of the convicted guilt."]

The 2019 Draft of Criminal Code, precisely in Book I, also regulates the concept of customary criminal law in Article 2 paragraph (1) and (2), Article 66 paragraph (1) e, Article 96, Article 97, Article 116, and Article 120. The inclusion of these articles in the Draft means that the draft adheres to the doctrine of being against material law, both in its positive and negative functions. The doctrine of unlawful nature of formal law determines that an act is against the law, if it is contrary to written law or legislation. The teaching of unlawful nature determines that an act against the law is not only against the written law or legislation but also contradicts the legal principles that live within society. ${ }^{8}$

Based on the description, this study aims to examine the prospects or new paradigms of future criminal law policies to formulate criminal sanctions in cases of customary crimes.

\section{B. Customary Law in Indonesian Regulation}

The concept of crime always develops based on place and time. Each indigenous community have their own perception of offenses or criminal law. Haar argues that offense or violation is the existence of a unilateral act, which according to the other party expressly or secretly disturbs the balance. The customary criminal law covers events and actions of offenses and the resolutions to maintain the balance of society.

Based on the perspectives of the comparison study and the knowledge study, the approval of the law exists that alive or the law which is not written as the sources of the law are not rare occasions. These could be explained as of these examples:

a. Ordinary Law or the law which are alive who get the place and also consider as the sources of law within the tradition either the common law system or traditional law system (traditional system law)

b. There is the theory/ doctrine/ learning "SMH ( act against the law) material", theory of "functional action" or definition of "act viewed from science", there the doctrine "there is no punishment without guilt", and the approval "experts

$8 \quad$ I Dewa Made Suartha, op.cit., p. 324. 
opinion" or "science" in the practice of the law enforcement, in general, it means the terms that eligible to become the sources of law (the certain sources) not only the formal certainty based on UU (written law), it also "the certainty of material / substantial". So, not only the availability of "certainty of law" or "formal certainty" there are also "certaintycertainty) unwritten law" or "substantive/ material certainity".

c. The times explaining the Netherland KUHP, Lessing speaks in general if, formally, it's true "case law/ unwritten la/ongeschreven recht" as not the true sources of law. however, in the act of case law, it is the crucial sources of law, including the approval of the reasons for the deletion of the punishment outside of the act such as "the absence act of fights the law" (absence of blame unlawfullness) and "the absence of fault/negative approach" (absence of blame wirthiness). ${ }^{9}$

In customary law, humans are members of community. The primary focus is the community. Humans live to achieve the goals of the community. Therefore, individual life is intended to serve the community. On the other hand, individuals have rights that are given in accordance with their duties within society. In other words, legal associations expect individuals to exercise their legal power in compliance with social goals. ${ }^{10}$ Based on Haar's statement, Hadikusuma argues that customary criminal law is a law that shows events and actions to be resolved or punished because the events and actions disturb the balance of community. Haar assumes that violation (delict) is every one-sided disturbance (eenzijding) of the balance and every one-sided collision on the material and immaterial life goods of one person or of many people who are a unit (a group) of people). Such action causes a reaction with nature and size based on customary reaction. The balance can and must be restored (mostly by way of payment of violations in the form of goods or money). An action is considered a customary crime based on the negative effect that it makes within the community. The negative effect occurs not only when legal regulations in a society are violated but also when the norms of morality, religion, and courtesy are violated. ${ }^{11}$

In general, customary criminal law covers any acts that violate the feelings of justice and propriety within community, causing disturbances to the peace and balance of the community. Therefore, to restore peace and balance, customary reactions occur to restore conducive situation. ${ }^{12}$ Customary justice is still found in several areas in Indonesia. for instance, in Tapanuli, the Dalihan Na Tolu is a traditional institution expected to provide solutions to conflicts within the Tapanuli

\footnotetext{
9 Barda Nawawi Arief, Perkembangan Asas-Asas Hukum Pidana Indonesia (Perspektif Perbandingan Hukum), Semarang: Pustaka Magister, 2008, pp. $24-25$.

10 Helnawaty, "Hukum Pidana Adat dalam Pembaharuan Hukum Pidana Nasional", Bina Mulia Hukum, Vol. 6, No. 2, 2017, pp. 149-160.

11 Ferry Kurniawan, op.cit., p. 15.

$12 \quad$ Ibid, p. 17.
} 
Indigenous community. In Kalimantan, there is inauguration of the Kedamangan institution. ${ }^{13}$ Peace is a symbol of the customary law community units in Indonesia. It is commonly known by the terminology of courts of adat, adat para-paras, adat pokara, or rapat adat, etc. ${ }^{14}$

Customary law can be a source of positive law. It means that customary criminal law can be the legal basis for examination in court. The provisions of customary law can be a reason for mitigating or increasing punishment. Considering that law cannot be separated from society, there is also reason to say that legal source of customary criminal law is the community as the subject. The substantive problems of duality between customary criminal law and national criminal law will automatically be resolved because the law that will later be built is a law that really comes from the community; and the law contains values living within the community. Thus, the law will always be linear with the demands of justice from the whole community, and customary criminal law in the future will become a source of law and become the basis for the formation of national criminal law. ${ }^{15}$

An act is declared a crime if the act has been declared a crime in the law. If the events and actions are not regulated, it cannot be considered an offense. This is called the principle of legality. Article 1 paragraph (1) of the Criminal Code reads: "Suatu perbuatan tidak dapat dipidana, kecuali berdasarkan kekuatan ketentuan perundang-undangan pidana yang telah ada" (An act cannot be punished, except the punishment is based on the strength of the provisions of the existing criminal legislation). Customary Criminal Law focuses on the "disturbed balance". If the balance of an indigenous community is disturbed, it will be subject to sanctions. Customary criminal law does not recognize the principle of legality as positive law because apart from its simple legal provisions, it basically does not recognize codification. Written law is not only related to law that are in written form but it is also related to institution. In other words, customary criminal law does not recognize written law even though some indigenous peoples in Indonesia are familiar with the codification of customary law. The institution that forms it is a customary association, not an authorized state authority. The customary law in Indonesia can be found in the books of Kuntara Raja Niti (Lampung), Manawa Dharmasastra, Catur Agama, Awig-Awig (Bali), Babad Jawa (Ancient Java), etc. In essence, an act is considered a violation if the act disrupts an established indigenous community. ${ }^{16}$

13 Herlambang Perdana Wiratraman, "Perkembangan Politik Hukum Peradilan Adat", Mimbar Hukum-Fakultas Hukum Universitas Gadjah Mada, Vol. 30, No. 3, 2018, p. 492.

14 Siti Chadijah, "Pengaturan Delik Adat dalam Rancangan KUHP sebagai Bagian dari lus Constituendum", Pamulang Law Review, Vol. 2, No. 2, 2020, p. 106.

Ibid, p. 18.

$16 \quad$ Ibid, p. 15. 


\section{The Urgency of Customary Criminal Law Incorporation into Criminal Law Reform}

In essence, customary law (including customary criminal law and customary justice) is a crystallization of values that live within society. The recognition is legitimized by the constitution. Article 18B paragraph (2) of the 1945 Constitution of the Republic of Indonesia states that the state recognizes and respecting customary law community units and their traditional rights. In addition, Article 6 paragraph (1) of the Law Number 39 of 1999 on Human Rights regulates that in the context of upholding human rights, differences and needs in customary law communities must be considered and protected by law, society, and government. ${ }^{17}$ In the framework of the formation of national law towards legal unification, one cannot ignore the customary law. It is an important source to obtain materials because it has universal principles, or values, and institutions. National culture that contains universal values is harmony in social interaction. ${ }^{18}$

Handling and checking the traditional cases involving the people needs logical interpretation and consideration by the judge that is not only based on written law of the regulation of the legislation only. Limited formalism legality of the principle only gives protection to an individual of the perpetrator and less give protection to people/ group of people that becomes the victim of the criminal act, so to give access of fairness to the victim especially the paused collective victim. Even though the legality of the principle approves as the fundamental principles, but the application is not effective when that act fights with the general law principle approved by people internationally. the enforcement of the punishment law by a retroactive method are the exception from legality principle as based of "extra ordinary crimes", such as the hard violation of the HAM. the enforcement of the criminal law with the retroactive method act as the balancer of the legality principle which is only attached to "certainty of law" and "the principle of fairness to all". the action of the criminal law within the retroactive method with several special conditions could be accepted to fulfil the moral demands of the people retaliation. ${ }^{19}$

The 1945 Constitution is essentially a grand document about Indonesian people, which includes constitutional arrangements regarding law, ideology, politics, economics, social, culture, defense, and security. The constitutional arrangements include the rights of indigenous communities. The rights of these communities, of course, include the recognition of the norms and values of the

17 Budi Suhariyanto,"Problema Penyerapan Adat oleh Pengadilan dan Pengaruhnya Bagi Pembaruan Hukum Pidana Nasional", Mimbar Hukum-Fakultas Hukum Universitas Gadjah Mada, Vol. 30, No. 3, 2018, p. 423.

18 Riezka Eka Mayasari, "Tantangan Hukum Adat dalam Era Globalisasi sebagai Living Law dalam Sistem Hukum Nasional", Journal Equitable, Vol. 2, No. 1, 2017, p. 102.

19 Nyoman Serikat Putra Jaya, Pemberlakuan Hukum Pidana Secara Retroaktif sebagai Penyeimbang Asas Legalitas dan Asas Keadilan (Suatu Pergeseran Paradigma dalam IImu Hukum Pidana), Semarang: Badan Penerbit Universitas Diponegoro, 2013, pp. 47-48. 
community. Prior to the amendment, the 1945 Constitution gave recognition to the existence of indigenous peoples. It must be acknowledged that the recognition of the indigenous peoples received more recognition after the amendment. In the amended 1945 Constitution, there are at least three provisions that provide recognition of the existence of indigenous peoples.

1. Article 18B paragraph (2) explicitly states that the state recognizes and respects customary law community units and their traditional rights as long as they are still alive and in accordance with community development and the principles of the Unitary State of the Republic of Indonesia, which are regulated by law.

2. In addition to Article 18B paragraph (2) of the 1945 Constitution, Article 28I paragraph (3) also explicitly acknowledges the existence of indigenous peoples. The provisions of Article 281 paragraph (3) reads "Identitas budaya dan hak masyarakat tradisional dihormati selaras dengan perkembangan zaman dan peradaban" (Cultural identity and rights of traditional communities are respected in line with era and civilization development).

3. In addition to the two articles, Article 32 paragraph (1) and (2) of the 1945 Constitution affirms that the state shall promote Indonesian national culture amid world civilization by guarantee the freedom of society in maintaining and developing its cultural values; and that the state respects it. ${ }^{20}$

Customary Criminal Law focuses on the "disturbed balance". If the balance of an indigenous community is disturbed, it will be sanctioned. Customary criminal law does not recognize the principle of legality as positive law because in addition to simple legal provisions, customary criminal law does not recognize codification. In other words, customary criminal law does not recognize written law even though some indigenous peoples in Indonesia are familiar with the codification of customary law. ${ }^{21}$ The concept of restoring balance is related to universal principles of law, namely the principle of justice. The importance of including customary criminal law or customary criminal law values in criminal law reform is caused philosophical, juridical, and sociological aspects.

Philosophically, customary law is an embodiment of the values and nature of customary law, which is very identical and has even been contained in the Indonesian philosophy: Pancasila. Pancasila is the crystallization of customary law. Customary law or local community customs as convention does not require procedures or efforts like written law. However, they can be applied by the community voluntarily. Customary law is the living law because the community use it. It is implemented and obeyed by the people without having to go through the

\footnotetext{
20 Tongat, Said Noor Prasetyo and Yaris Adhial Fajrin, "Hukum yang Hidup dalam Masyarakat dalam Pembaharuan Hukum Pidana Nasional", Jurnal Konstitusi, Vol. 17, No. 1, 2020, p. 170.

21 Asliani Harahap, op.cit., p. 2.
} 
promulgation procedures in the state gazette. ${ }^{22}$ As an ideology, Pancasila is teaching, idea, doctrine, theory, or science that is believed to be true and is used as a way of life for the Indonesian people. It guides the problem solving by people, nation, and state. Thus, the ideology of Pancasila is the teachings, doctrines, theories, and/or knowledge of the ideals of the people. They are believed to be true and systematically compiled and given instructions with clear implementation. ${ }^{23}$ Pancasila is the legal basis and source of national law according to the following national seminars and conventions.

(a) The Second National Law Seminar states that if an implementation of the 1945 Constitution contradicts the spirit and the essence of Pancasila, the implementation is a manipulation of the constitution and a betrayal on Pancasila.

(b) The Fourth National Law Seminar states that Pancasila is the people's psychological values; the basis of Indonesian legal order, guidelines, and directions; and the touchstone of decency and legislation. The reflection of Pancasila values in the legislation is the essence of the formation of a national legal system.

(c) The Fifth National Law Seminar in 1990 states that at the end of Fourth Five Year Development Plan (Repelita VI, stands for Rencana Pembangunan Lima Tahun VI), the mindset and framework of the national legal system should be formulated based on Pancasila and the 1945 Constitution.

(d) The Sixth National Law Seminar in 1994 states that the national legal system, the Pancasila legal system, must be an elaboration of the integrated Pancasila precepts.

(e) The recommendation of the 2008 National Law Convention states that it is necessary to draw up a Grand Design of the National Legal System and Politics with the 1945 Constitution as the constitutional basis and Pancasila as the philosophical basis. ${ }^{24}$

The seminars clearly show that the expected national law is a law based on Pancasila. The similar principle lies on the problems of criminal law. The current criminal code has long been a problem because it is a colonial product that does not describe the cultural, social, and philosophical existence of the Indonesian people. Indonesians emphasize ethics and morals in daily lives, not only in normative law. The Criminal Code does not regulate the weighting of penalties for theft of sacred objects. The Criminal Code does not regulate the weighting of penalties for theft of sacred objects. For instance, Article 363 of the Criminal Code

\footnotetext{
22 Endrawati, L, “Konsep Transplantasi Sanksi Pidana Adat melalui Pendekatan Hukum Progresif ke dalam Hukum Pidana Nasional sebagai Upaya Pembaharuan Kebijakan Hukum Pidana”, Journal of Indonesian Adat Law (JIAL), Vol. 2, No. 3, 2018, p. 153.

23 Muhammad Chairul Huda, "Meneguhkan Pancasila sebagai Ideologi Bernegara", Resolusi: Jurnal Sosial Politik, Vol. 1, No. 1, 2018, p. 91.

24 Derita Prapti Rahayu, Budaya Hukum Pancasila, Yogyakarta: Thafa Media, 2014, pp. 70-71.
} 
defines serious theft as a theft at night in a house or a closed yard where there is a house, which is carried out by person who is there, unknown or unwanted by entitled party, which is followed by an act in which the theft is committed by the person who is there. It also must involve two or more persons or theft that enter the place to commit crime, or to arrive at the stolen goods, is carried out by breaking, cutting or climbing, or by using false keys, false orders or false official clothes.

Efforts to reform the Criminal Code to replace the one that is inherited from the colonial era, urgently require a study with comparative and constructive materials. The study of family law, which is closer to the characteristics of society and sources of law in Indonesia, is very urgent. ${ }^{25}$ The Criminal Code does not stipulate a crime for men who refuse to be responsible for their partner's pregnancy. In Bali, such acts are punishable based on the Lokika Sanggraha offense. Pancasila is unique because the values have a fixed and sequential position. Each principle cannot be separated from others. ${ }^{26}$

The juridical aspect can be seen from the wishes of many parties who expect that an excavation of living law should be carried out to replace the old criminal law for various reasons, including the old criminal law; or the Criminal Code is outdated and not in accordance with the Indonesia ethics and norms. This discrepancy can be seen from several articles in the Criminal Code that do not heed the people's values, the values of existing norms, and cultural and religious values within society. One of them is the provision on the principle of formal legality. The customary crimes that can be included in Indonesian criminal law cannot be separated from the desire of parties. Therefore, Indonesian criminal law must emphasize more on the laws of the Indonesian nation and leave the old laws adopted from the colonial era. The following are some articles in the Criminal Code that are not in accordance with the era and cultural customs of the Indonesian people.

Article 1 paragraph 1 of the Criminal Code contains the principle of legality. The article states that a person cannot be punished if the actions are not in the statutory regulations. This paragraph narrows the role of judges who in legislation, apart from being a judge as an adjudicate of a case which already has rules, must also explore the legal values that exist within society. This is in accordance with Article 5 paragraph 1 of the Law Number 48 of 2009 on Judicial Power. It clearly states that judge and constitutional judge is obliged to dig, abreast of the Constitution, and to understand the values of law and a sense of justice that lives with in community".

25 Barda Nawawi, Kapita Selekta Hukum Pidana, Bandung: Citra Aditya Bakti, 2013, p. 36.

26 M.S Alfarisi, "Politik Hukum Pidana Adat dalam Pembaharuan Hukum Pidana Indonesia", Jurnal Yuridis Unaja, Vol. 1, No. 1, 2018, p. 28. 
The judge must decide a case by using written law. Subsequently, in the absence of the written law, the judge must find it in jurisprudence, doctrine, treaty, custom or unwritten law. ${ }^{27}$ Article 1 paragraph 1 of the Criminal Code should not be enforced because it must provide space for judges to use their authority independently to decide a case fairly even though the case does not exist or no rules governing it. Article 1 paragraph 1 of the Criminal Code closes the obligation of judges to explore the values that live in society in deciding cases. Article 1 paragraph 1 of the Criminal Code should not be a reference anymore because of the legality principle. With the existence of a judge's decision who decides cases in accordance with the laws that live in the community, in accordance with Article 5 paragraph 1 of Law Number 48 of 2009 on Judicial Power, the judge's decision can be a case law for other judges when examining, adjudicating, and deciding on the same case.

Sociologically, law determines how we will live in society; how prosperity and social welfare are enjoyed equally; and how justice can be realized in real life. The absence of a national law that is in accordance with the conditions of present life, while the existing laws inherited from the Dutch colonial period and are still being stipulated today, are no longer suitable. It causes some members of our society to lose their grip on the law in their lives. This can be seen from the softening of the sense of social responsibility in most members of society, the attitude of disobedience and defiance to the law, the attitude of disrespecting the rights of others, corruption, and other despicable acts. ${ }^{28}$

\section{The Formulation of Future Criminal Sanctions in the Settlement of Customary Criminal Cases}

The reform of Indonesian criminal law is directed to accommodate the laws that live within society into the content of formal criminal law. It is a form of criminal politics through efforts to criminalize some acts. It is an effort to suppress crimes in society and at the same time to create welfare. Conduciveness is one of the supporting factors for the creation of community welfare. ${ }^{29}$ The future of Indonesian law reform is currently directed at efforts to reorient the substance of the criminal law rules, which are considered no longer relevant to the life of the Indonesian people because many evil acts in the public eye are not included as evil acts and are prohibited in the positive law perspective. Indonesian criminal law in general is inherited from the Dutch colonial eta. It is culturally different from the Indonesian culture. Law reflects a society, but the current Indonesian criminal law

Ibid, p. 28.

Helnawaty, op.cit., p. 151.

Sunantara, I. G. H, "Arah Pembaharuan Hukum Pidana Indonesia dan Kontribusi Hukum Pidana Adat di Tengah Pluralisme Hukum Indonesia", Kertha Semaya: Journal IImu Hukum, Vol. 8, No. 12, pp. 1972-1983. 
does not. Current reform of Indonesian criminal law leads to a re-orientation of the substance of Indonesian criminal law in accordance with the will of the people. ${ }^{30}$

The drafters of the National Criminal Code have succeeded in compiling the Concept of the Criminal Code in the House of Representatives (DPR -Dewan Perwakilan Rakyat). Several articles still need to be discussed jointly between the Government and the House of Representatives. The concept of the Criminal Code consists of two books: Book I on General Provisions and Book II on Crime. Customary Criminal Law has a place in both books. In Book I, the concept of customary criminal law is regulated in the following articles.

Article 1, The Concept of Criminal Code:

"(1) No one can be convicted or subject to action unless the act committed has been determined as a criminal offense in the prevailing laws and regulations at the time the act is committed.

(2) In determining the existence of a criminal act, analogy is prohibited."

Article 2, The Concept of Criminal Code:

"(1) The provisions as referred to in Article 1 paragraph (1) does not reduce the validity of laws living within society, which determine that a person should be sentenced even though the act is not regulated in legislation.

(2) The law that lives in society as referred to in paragraph (1) is applicable if it is in accordance with the values contained in Pancasila, human rights, and general legal principles recognized by the community of civilized nations."

Based on the concept of the Criminal Code, the legal source or legality basis to declare an act as a criminal act is not only based on the legality principle of the law (Article 1). It is also based on the principle of material legality by giving place to "living law/unwritten law." (Article 2). Nawawi says that the principle of formal legal certainty is also balanced with the principle of legal certainty materially. In other words, the unlawful nature of an act must be based on a formal legality but it does not reduce the existence of an unlawful nature materially (material legality). ${ }^{31}$

The Draft of Criminal Code has accommodated this material legality principle in Article 2 paragraph (1) and (2). It states that the provisions of the formal legality principle do not reduce the validity of laws that live in society. It determines that a

\footnotetext{
30 Fajrin, Y. A. and Triwijaya, A. F., "Arah Pembaharuan Hukum Pidana Indonesia di Tengah Pluralisme Hukum Indonesia", Ekspose: Jurnal Penelitian Hukum dan Pendidikan, Vol. 18, No. 1, 2019, p. 739.

31 Nyoman Serikat Putra Jaya, "Posisi Hukum Adat dalam Pembaharuan KUHP," Webinar Material for the IKFH Diponegoro University, accessed on January 2021.
} 
person deserves to be convicted even though the act is not regulated in statutory regulations. The enactment of laws that live in society as the basis for the punishment of a person is the principle of material legality. However, this enforcement is limited by the values contained in Pancasila, human rights, and general legal principles recognized by the people of nations. ${ }^{32}$ Although the concept of giving place to convention/living law/customary law as a source of law, the concept also limits the application of living law as follows. ${ }^{33}$

1. Article 2 paragraph (1): the act is not regulated in legislation.

2. Article 2 paragraph (2): if the laws that live in that society are in accordance with the values of Pancasila, human rights and/or general legal principles recognized by the people of nations.

The values contained within communities are closely related to the actions that are considered evil by the customary communities. The prohibitions within customary communities are the illustration. An evil act in the terms of criminal law is often referred to as a criminal act. ${ }^{34}$ With the inclusion of customary sanctions in the form of fulfilling customary obligations in the 2019 Draft of Criminal Code, even though it is only an additional punishment, judges who serve in the District Courts and High Courts have no more doubts in imposing customary sanctions. This means that the customary communities' dissatisfaction with the Court's decision in passing on judicially customary crimes, which only imposes crimes in accordance with Article 10 of the current Criminal Code can be eliminated. The balance of the community which is disturbed because of the customary crime can be fulfilled for the sense of justice in the customary communities. ${ }^{35}$

If it is related to the purpose of punishment in the form of general and specific prevention, the existence of customary sanctions in the form of fulfilling customary obligations can prevent the indigenous people from committing acts that cause shocks. For example, when there is an adultery, there is a customary sanction to the perpetrator. The perpetrator, who is the target of the sanction, can improve to become a good member of society. Furthermore, additional penalties in the form of customary obligations also contain a community protection dimension to protect customary communities from despicable acts. In reality, customary sanctions are in the form of fulfilling customary obligations. For example, by holding a meprayascitta ${ }^{36}$ ceremony, the customary communities feel protected by magical disturbances. ${ }^{37}$

\footnotetext{
32 Muhammad Azil Maskur, "Internalisasi Nilai-nilai Masyarakat Adat dalam Pembaharuan Hukum Pidana Nasional", Masalah-Masalah Hukum, Vol. 47, No. 1, 2018, p. 30.

Ibid.

Muhammad Azil Maskur, op.cit., p. 27.

I Dewa Made Suartha, op.cit., p. 324.

Meprayascitta is a ceremony to cleanse body and soul according to Balinese adat law.

I Dewa Made Suartha, op.cit., p. 326.
} 
Therefore, for the purpose of the formulation of criminal sanctions in the future, the objectives of punishment in the settlement of customary crimes are: ${ }^{38}$

(1) to impose criminal sanctions (both as principal and additional criminal sanctions) since the Criminal Code (WvS) so far are unable to fulfill the purpose of criminalization and does not fulfill the sense of justice of customary communities;

(2) to impose customary sanctions, like the customary law (awig-awig) ${ }^{39}$ in each Traditional Village/Pakraman ${ }^{40}$ in Bali that has been able to fulfill the sense of justice of customary communities since the customary law is made by and for customary communities; and

(3) to impose criminal sanctions (as the principal criminal sanctions and customary sanctions in the form of customary obligations as additional criminal sanctions or at the same time customary sanctions as the principal criminal sanctions/dual function) will be able to fulfill the purpose of punishment and the sense of justice of the customary communities.

The formulation of Article 2 paragraph (2) can be expected to become criteria or signs/guidelines for judges in determining "the law that lives in society" or "The Living Law" as a source of law (material legality) in the future. It can be a form of a new paradigm in the reform of customary criminal law. Thus, customary (criminal) law can be a source of positive law and a source of negative law. As a positive source of law, customary criminal law/sanctions can be the legal basis for case examination at the District Court. As a negative source of law, the customary criminal law/sanctions can be a justification or an excuse to alleviate or increase the punishment. ${ }^{41}$

\section{Conclusion}

The customary law in the renewal of the Criminal Code is placed as an equal. It means that the law within society can function as a source of law to determine act that must be punished (material legality) in addition to be based on law (formal legality). Customary law can be a source of reform of the Criminal Code in Indonesia, considering that judges have a legal obligation to explore the values that live and develop in society. Customary sanctions in the form of fulfilling customary obligations or fulfilling legal obligations within society function as additional

Ibid.

39 Awig-awig is a written rule made by the Traditional Village / pakraman and applies within the area/authority of the relevant Traditional Village/Pakraman in Bali.

40 Traditional Village/Pakraman is an area in Bali that is occupied by a number of residents as a legal community unit that has a government and is entitled to run its own household (original autonomy) within the Unitary State of the Republic of Indonesia (Article 18 B paragraph (2) of the 1945 Constitution in conjunction with Bali Regional Regulation Number 3 of 2001 on Pakraman.

41 I Dewa Made Suartha, loc.cit. p. 324. 
penalties in general. It can also be seen as the main punishment for actions that according to living law can be punished or prohibited. Harmonization between customary criminal law and national criminal law is a form of justice and must be based on the benefit of the people. Therefore, customary sanctions against cases of customary crimes are resolved through the law that lives in the community as material legality.

\section{References}

\section{Books}

Barda Nawawi Arief, Kapita Selekta Hukum Pidana, Citra Aditya Bakti, Bandung, 2013. , Perkembangan Asas-Asas Hukum Pidana Indonesia (Perspektif Perbandingan Hukum), Penerbit Pustaka Magister, Semarang, 2008.

Derita Prapti Rahayu, Budaya Hukum Pancasila, Thafa Media, Yogyakarta, 2014.

I Dewa Made Suartha, Hukum dan Sanksi Adat Perspektif Pembaharuan Hukum Pidana, Setara Press, Malang, 2015.

Nyoman Serikat Putra Jaya, Pemberlakuan Hukum Pidana Secara Retroaktif sebagai Penyeimbang Asas Legalitas dan Asas Keadilan (Suatu Pergeseran Paradigma dalam IImu Hukum Pidana), Badan Penerbit Universitas Diponegoro, Semarang, 2013.

Sudarto, Hukum Pidana I, Yayasan Sudarto, Semarang, 2009.

\section{Other Documents}

Asliani Harahap, "Pembaharuan Hukum Pidana Berbasis Hukum Adat", EduTech: Jurnal Ilmu Pendidikan dan Ilmu Sosial, Vol. 4, No. 2, 2018.

Budi Suhariyanto,"Problema Penyerapan Adat oleh Pengadilan dan Pengaruhnya Bagi Pembaruan Hukum Pidana Nasional", Mimbar Hukum-Fakultas Hukum Universitas Gadjah Mada, Vol. 30, No. 3, 2018.

Endrawati, L., "Konsep Transplantasi Sanksi Pidana Adat melalui Pendekatan Hukum Progresif ke dalam Hukum Pidana Nasional sebagai Upaya Pembaharuan Kebijakan Hukum Pidana", Journal of Indonesian Adat Law (JIAL), Vol. 2, No. 3, 2018.

Fajrin, Y. A. and Triwijaya, A. F., "Arah Pembaharuan Hukum Pidana Indonesia di Tengah Pluralisme Hukum Indonesia", Ekspose: Jurnal Penelitian Hukum dan Pendidikan, Vol. 18, No. 1, 2019.

Fery Kurniawan, "Hukum Pidana Adat sebagai Sumber Pembaharuan Hukum Pidana Nasional", EDUKA, Jurnal Pendidikan, Hukum, dan Bisnis, Vol. 2, No. 2, 2016.

Galuh Faradhilah Yuni Astuti, "Relevansi Hukum Pidana Adat dalam Pembaharuan Hukum Pidana di Indonesia", Jurnal Pandecta, Vol. 10, No. 2, 2015.

Helnawaty, "Hukum Pidana Adat dalam Pembaharuan Hukum Pidana Nasional”, Binamulia Hukum, Vol. 6, No. 2, 2017. 
M.S Alfarisi, "Politik Hukum Pidana Adat dalam Pembaharuan Hukum Pidana Indonesia", Jurnal Yuridis Unaja, Vol. 1, No. 1, 2018.

Muhammad Azil Maskur, "Internalisasi Nilai-nilai Masyarakat Adat dalam Pembaharuan Hukum Pidana Nasional", Masalah-Masalah Hukum, Vol. 47, No. 1, 2018.

Nyoman Serikat Putra Jaya, "Posisi Hukum Adat dalam Pembaharuan KUHP," Webinar Material for the IKFH Diponegoro University, Semarang on January 23, 2021.

Rahmat Hi. Abdulah, "Urgensi Hukum Adat dalam Pembaharuan Hukum Pidana Nasional", Fiat Justisia Jurnal Ilmu Hukum, Vol. 9, No. 2, 2015.

Riezka Eka Mayasari, "Tantangan Hukum Adat dalam Era Globalisasi sebagai Living Law dalam Sistem Hukum Nasional", Journal Equitable, Vol. 2, No. 1, 2017.

Sunantara, I. G. H. "Arah Pembaharuan Hukum Pidana Indonesia dan Kontribusi Hukum Pidana Adat di Tengah Pluralisme Hukum Indonesia", Kertha Semaya: Journal Ilmu Hukum, Vol. 8, No. 12.

Tongat, Said Noor Prasetyo, and Yaris Adhial Fajin, "Hukum yang Hidup dalam Masyarakat dalam Pembaharuan Hukum Pidana Nasional", Jurnal Konstitusi, Vol. 17, No. 1, 2020.

\section{Legal Documents}

Provisional People's Consultative Assembly Decree Number XX/MPRS/1996 [Ketetapan Majelis Permusyawaratan Rakyat No. XX/MPRS/1996].

The Law Number 12 Year 2011 on the Procedures of the Establishment of Laws and Regulations [Undang-Undang Nomor 12 Tahun 2011 tentang Tata Cara Pembentukan Peraturan PerundangUndangan].

The Law Number 1 of 1951 on Emergency Act [Undang-Undang Nomor 1 Tahun 1951 tentang Tindakan-Tindakan Sementara untuk Menyelenggarakan Kesatuan Susunan Kekuasaan dan Acara Pengadilan-Pengadilan Sipil].

The Law Number 1 of 1946 on Criminal Law [Undang-Undang Nomor 1 Tahun 1946 tentang Peraturan Hukum Pidana].

The Law Number 48 of 2009 on Judicial Power [Undang-Undang Nomor 48 Tahun 2009 tentang Kekuasaan Kehakiman]. 